\title{
की

\section{Improvement of Granular Subgrade Soil by Using Geotextile and Jute Fiber}

\author{
Md. Akhtar Hossain, Akib Adnan, Md. Maskurul Alam \\ Department of Civil Engineering, Rajshahi University of Engineering \& Technology, Rajshahi, Bangladesh
}

Email address:

akhtar412002@yahoo.com (Md. A. Hossain), akib_adnan@yahoo.com (A. Adnan), maskuru1090018@gmail.com (Md. M. Alam)

To cite this article:

Md. Akhtar Hossain, Akib Adnan, Md. Maskurul Alam. Improvement of Granular Subgrade Soil by Using Geotextile and Jute Fiber. International Journal of Science, Technology and Society. Vol. 3, No. 5, 2015, pp. 230-235. doi: 10.11648/j.ijsts.20150305.12

\begin{abstract}
Geotextiles and jute fibers both have been successfully used for reinforcement of soils to improve the bearing capacity. In the present study, firstly the geotextile is used as a tensional material for reinforcement of granular soils. Laboratory California Bearing Ratio (CBR) tests were performed to investigate the load-penetration behavior of reinforced and unreinforced granular soils with geotextile. By placing geotextile at certain depth within sample height in one, two or three layers were tested under soaked condition to investigate the effects of the number of geotextile layer on the increase in bearing capacity. Secondly, laboratory tests were performed to investigate the behavior of granular soil reinforced with jute fiber of various aspect ratio mixed with soil at $0.5 \%, 1.0 \%, 1.5 \%, 2.0 \%$ by weight of the soil. Finally, the granular soil was reinforced with the combination of geotextile (top and middle layer of the sample) and jute fiber ( $0.5 \%$ and $1 \%$ by the weight of soil). The experimental results were then studied and compared to determine the most effective combination of geotextile and jute fiber to reinforce the studied granular soil.
\end{abstract}

Keywords: CBR Tests, Jute Fiber, Geotextile, Bearing Capacity, Granular Soil

\section{Introduction}

The uses of geotextile in many engineering applications have become more apparent and have proven to be an effective means of soil improvement. Soil improvement in the broadest sense, is the alteration of any property of a soil to improve its engineering performance. It also comprises any process which increases or maintains the natural strength of soil. In early applications in roads and airfield construction, emphasis was laid on the load bearing function of the geotextile. Resl and Werner (1986) carried out the laboratory tests under an axi-symmetric loading condition using nonwoven, needle-punched geotextiles. The result showed that the geotextile layer placed between subbase and subgrade can significantly increase the bearing capacity of soft subgrades. Fannin and Sigurdsson (1996) carried out a full scale field trial to observe the performance of different geosynthetics in unpaved road construction over the soft ground. Numerous papers have examined the reinforcement of soil (Bergado et al., 2001; Raymond and Ismail, 2003; Park and Tan,2005; Yetimoglu et al., 2005 ). Current research works are mainly emphasized on improving the strength mechanism and bearing capacity of the reinforced soil by adding jute fiber and geogrid (Hossain et al., 2015; Allahbakhshi, M. and Sadeghi, H. 2014). In this study, CBR test carried out on nonwoven needle-punched geotextile combines with the granular soils, the geotextile reinforcement placed between three different subgrade layers and the comparison between bearing capacity of soil with and without geotextile reinforcement under axi-symmetric loading condition was investigated. Further tests were carried out of soil reinforced with jute fiber of various aspect ratios and a number of combined reinforcements.

\section{Methodology}

Samples with various geotextile layers and various percentage of jute fiber were prepared and tested. The test results were compared to determine the combination reinforcement. The combination reinforcement was applied and similar tests were performed.

Samples Tested

1. Sample without any reinforcement. 
2. Sample reinforced with $0.5 \%, 1.0 \%, 1.5 \%, 2.0 \%$ of $50 \mathrm{~mm}$ jute fiber.

3. Sample reinforced with $0.5 \%, 1.0 \%, 1.5 \%, 2.0 \%$ of $100 \mathrm{~mm}$ jute fiber.

4. Sample reinforced with $0.5 \%, 1.0 \%, 1.5 \%, 2.0 \%$ of $150 \mathrm{~mm}$ jute fiber.

5. Sample reinforced with single layer of geotextile (top, middle, bottom).

6. Sample reinforced with two layer of geotextile (topmiddle, top-bottom, middle-bottom).

7. Sample reinforced with three layer of geotextile (topmiddle-bottom).

8. Sample reinforced with $0.5 \%$ jute fiber $(50 \mathrm{~mm})$ and single layer (top) of geotextile.

9. Sample reinforced with $0.5 \%$ jute fiber $(50 \mathrm{~mm})$ and single layer (middle) of geotextile.

10. Sample reinforced with $1.0 \%$ jute fiber $(50 \mathrm{~mm})$ and single layer (top) of geotextile.

\section{Materials Used}

Collection of Soil Sample and It's Geotechnical Properties

Soil sample obtained locally is used for the present experimental investigations. Sample used in this research was collected from the bank of river Padma at Talaimari, Rajshahi. The required properties of the soil were determined and are presented on Table.3.1.

Table 3.1. Basic Geotechnical Properties of Soil Sample.

\begin{tabular}{ll}
\hline Optimum Moisture Content & 13 \\
Specific Gravity & 2.635 \\
Angle of Internal Friction & 34.14 \\
Finness modulus & 2.611 \\
\hline
\end{tabular}

Table 3.2. Basic Engineering properties of geotextile.

\begin{tabular}{ll}
\hline Weight $\left(\mathrm{g} / \mathrm{m}^{2}\right)$ & 175 \\
Thickness $(\mathrm{mm})$ & 0.9 \\
Static Puncture $(\mathrm{N})$ & 170 \\
Tensile Strength $(\mathrm{KN} / \mathrm{m})$ & 13 \\
Elongation at Peak Stress & $45-50 \%$ \\
\hline
\end{tabular}

Table 3.3. Basic Properties of Jute Fiber.

\begin{tabular}{ll}
\hline Weight per Unit Length $(\mathrm{gm} / \mathrm{cm})$ & 0.36 \\
Diameter $(\mathrm{mm})$ & 4 \\
& $50($ A.R. $=12.5)$ \\
Length $(\mathrm{mm})$ & $100($ A.R. $=25)$ \\
& $150($ A.R. $=37.5)$ \\
\hline
\end{tabular}

\section{Test Results}

Soil sample was mixed with $0.5 \%, 1.0 \%, 1.5 \%, 2.0 \%$ jute fiber of various length $(10 \mathrm{~mm}, 20 \mathrm{~mm}, 40 \mathrm{~mm})$ and reinforced with 1 layer, 2 layers, 3 layers of geotextiles.CBR tests were performed for all test samples. Optimum moisture content of sample with and without jute fibers (differently for each soil-fiber ratio) was experimentally achieved by Modified Proctor test. Later on various blends on jute fibers and geotextile layers were used to achieve similar or improved CBR values with less layers of geotextiles to reduce the overall cost of a project.

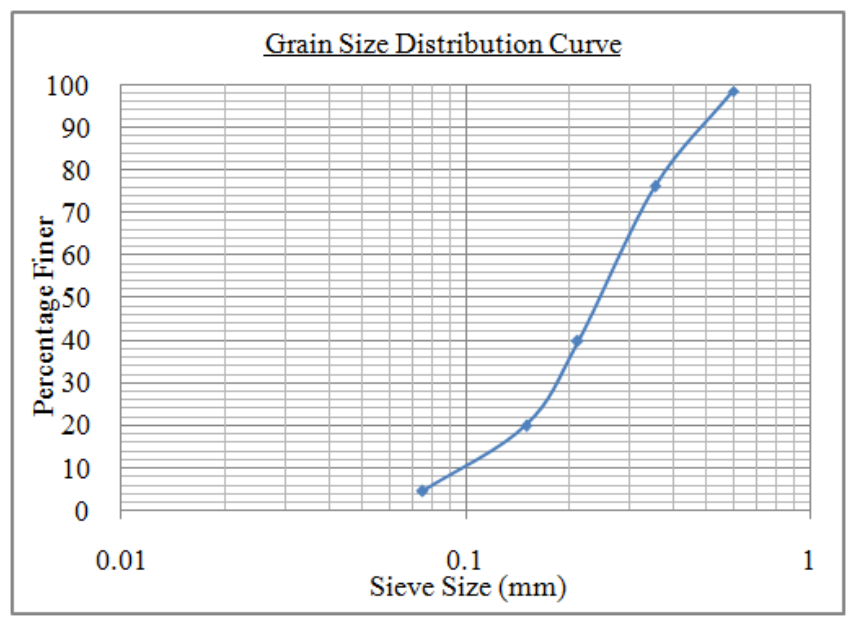

Fig. 4.1. Grain size distribution of Sample.

Table 4.1. Optimum moisture content of sample with and without jute fiber.

\begin{tabular}{ll}
\hline Jute Fiber Content(\% by weight) & $\begin{array}{l}\text { Optimum Moisture Content (\% } \\
\text { from Modified Proctor test) }\end{array}$ \\
\hline 0.0 & 13.5 \\
0.5 & 14.8 \\
1.0 & 15.6 \\
1.5 & 17.1 \\
2.0 & 18.6 \\
\hline
\end{tabular}

\subsection{CBR Test Results for Various Lengths and Amount of} Jute Fiber

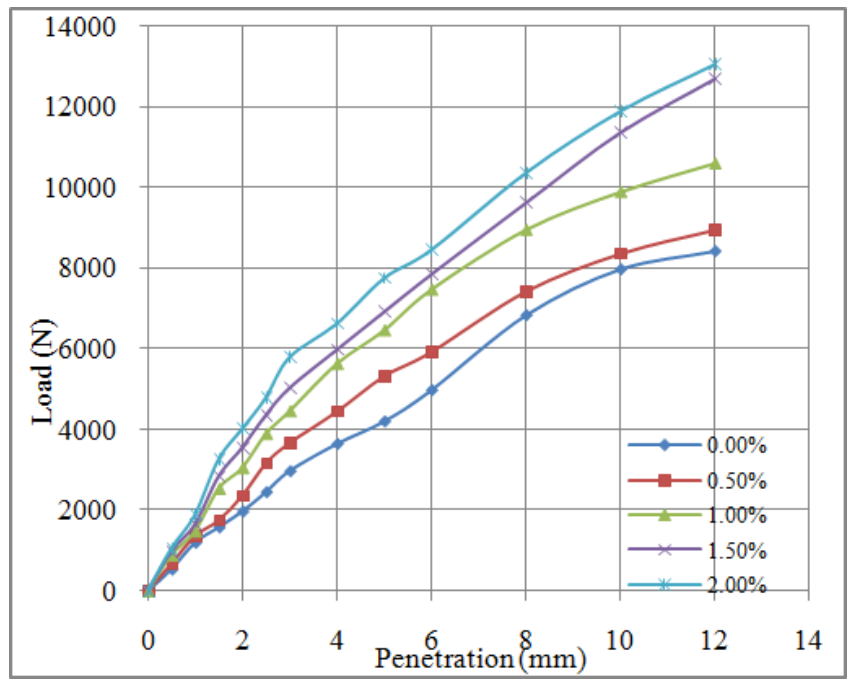

Fig. 4.2. Load vs Penetration Plot for various $\%$ of jute fiber $(50 \mathrm{~mm})$ mixed subgrade soil in unsoaked condition. 


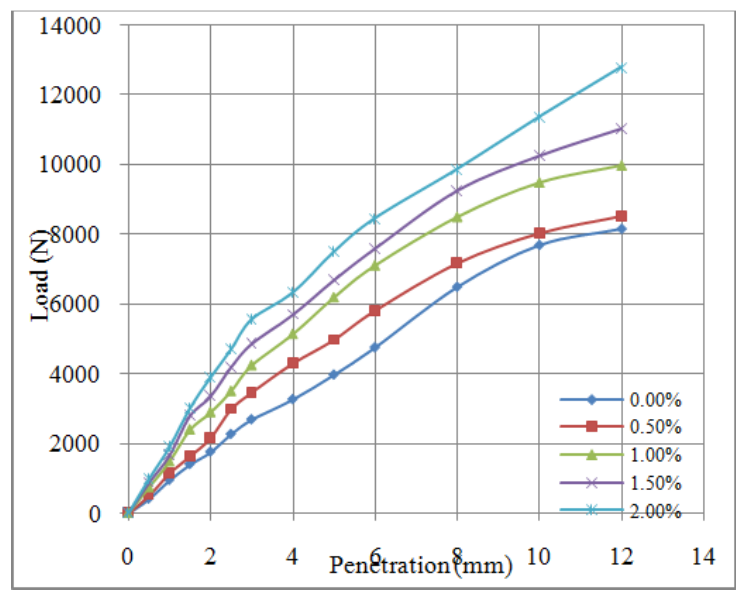

Fig. 4.3. Load vs Penetration Plot for various \% of jute fiber $(50 \mathrm{~mm})$ mixed subgrade soil in soaked condition.

Table 4.2. CBR Test Results for jute fiber $(50 \mathrm{~mm})$ mixed sample.

\begin{tabular}{|c|c|c|c|c|}
\hline \multirow{2}{*}{$\begin{array}{l}\text { \% of jute } \\
\text { fiber by } \\
\text { weight }\end{array}$} & \multicolumn{2}{|l|}{ Unsoaked } & \multicolumn{2}{|l|}{ Soaked } \\
\hline & $\begin{array}{l}\text { CBR } \\
\text { Value }\end{array}$ & $\begin{array}{l}\text { \% Increase } \\
\text { in CBR }\end{array}$ & $\begin{array}{l}\text { CBR } \\
\text { Value }\end{array}$ & $\begin{array}{l}\text { \% Increase } \\
\text { in CBR }\end{array}$ \\
\hline $0.0 \%$ & 17 & - & 15 & - \\
\hline $0.5 \%$ & 25 & 47.1 & 23 & 53.2 \\
\hline $1.0 \%$ & 29 & 70.25 & 27 & 80.1 \\
\hline $1.5 \%$ & 34 & 100.1 & 29 & 93.33 \\
\hline $2.0 \%$ & 36 & 111.5 & 32 & 113.6 \\
\hline
\end{tabular}

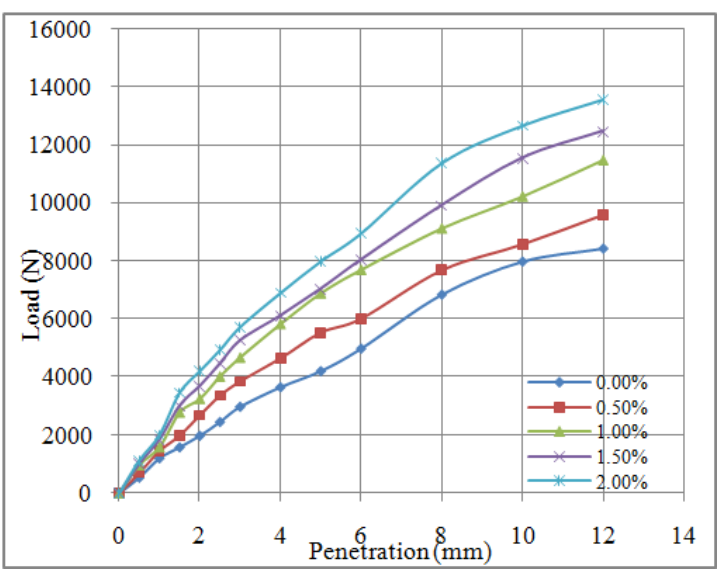

Fig. 4.4. Load vs Penetration Plot for various \% of jute fiber $(100 \mathrm{~mm})$ mixed subgrade soil in unsoaked condition.

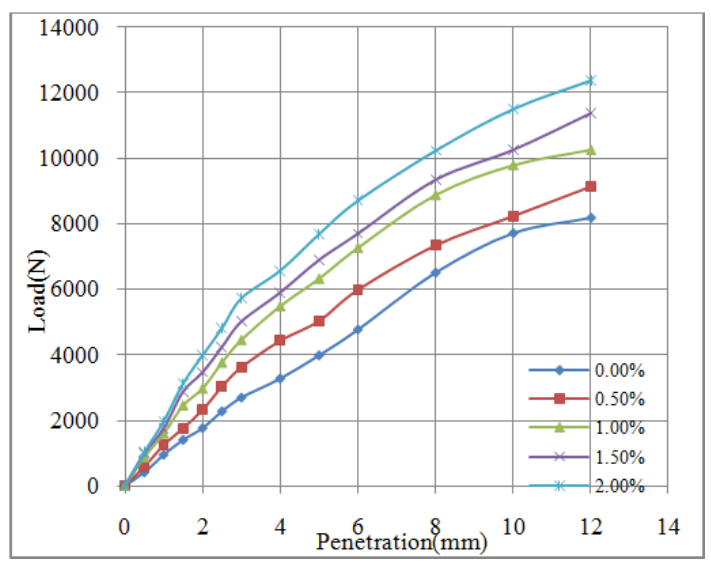

Fig. 4.5. Load vs Penetration Plot for \% of jute fiber $(100 \mathrm{~mm})$ mixed subgrade soil in soaked condition.
Table 4.3. CBR Test Results for jute fiber(100mm)mixed sample.

\begin{tabular}{|c|c|c|c|c|}
\hline \multirow{2}{*}{$\begin{array}{l}\% \text { of jute } \\
\text { fiber by } \\
\text { weight }\end{array}$} & \multicolumn{2}{|c|}{ Unsoaked } & \multicolumn{2}{|l|}{ Soaked } \\
\hline & $\begin{array}{l}\text { CBR } \\
\text { Value }\end{array}$ & $\begin{array}{l}\text { \% Increase } \\
\text { in CBR }\end{array}$ & CBR Value & $\begin{array}{l}\text { \% Increase in } \\
\text { CBR }\end{array}$ \\
\hline $0.0 \%$ & 17 & - & 15 & - \\
\hline $0.5 \%$ & 29 & 70.5 & 24 & 60 \\
\hline $1.0 \%$ & 33 & 94.1 & 28 & 86.6 \\
\hline $1.5 \%$ & 35 & 105.4 & 30 & 100 \\
\hline $2.0 \%$ & 37 & 117.7 & 31 & 106.6 \\
\hline
\end{tabular}

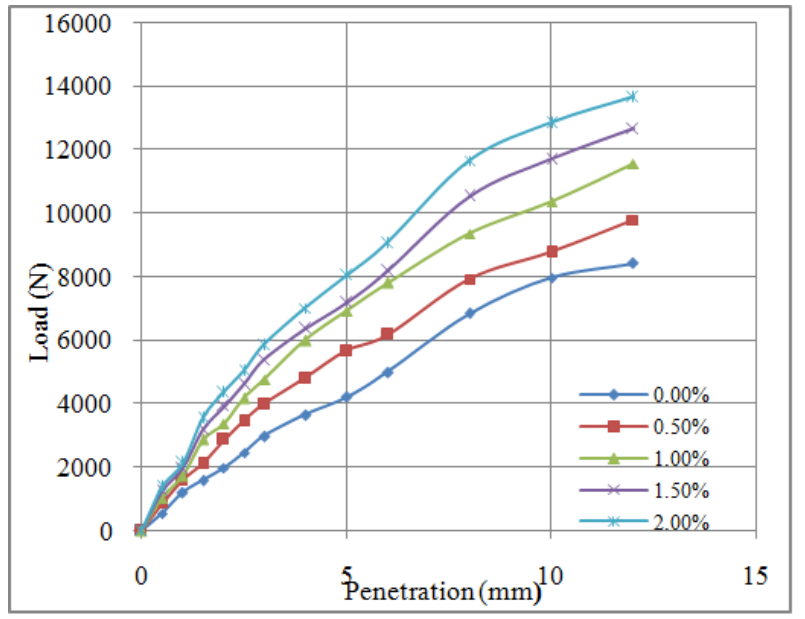

Fig. 4.6. Load vs Penetration Plot for \% of jute fiber $(150 \mathrm{~mm})$ mixed subgrade soil in unsoaked condition.

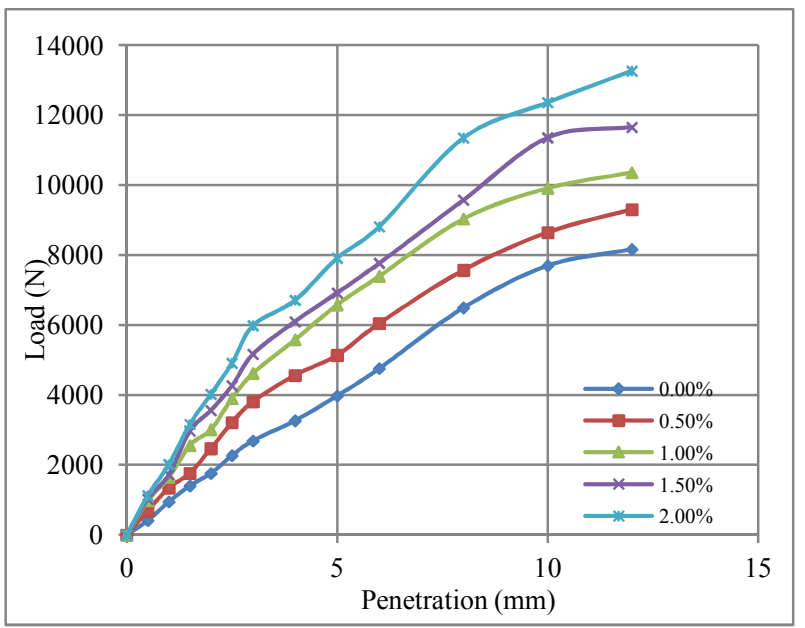

Fig. 4.7. Load vs Penetration Plot for \% of jute fiber $(150 \mathrm{~mm})$ mixed subgrade soil in soaked condition.

Table 4.4. CBR Test Results for jute fiber $(150 \mathrm{~mm})$ mixed sample.

\begin{tabular}{|c|c|c|c|c|}
\hline \multirow{2}{*}{$\begin{array}{l}\% \text { of jute } \\
\text { fiber by } \\
\text { weight }\end{array}$} & \multicolumn{2}{|c|}{ Unsoaked } & \multicolumn{2}{|c|}{ Soaked } \\
\hline & $\begin{array}{l}\text { CBR } \\
\text { Value }\end{array}$ & $\begin{array}{l}\text { \% Increase } \\
\text { in CBR }\end{array}$ & $\begin{array}{l}\text { CBR } \\
\text { Value }\end{array}$ & $\begin{array}{l}\text { \% Increase in } \\
\text { CBR }\end{array}$ \\
\hline $0.0 \%$ & 17 & - & 15 & - \\
\hline $0.5 \%$ & 30 & 76.4 & 25 & 66.6 \\
\hline $1.0 \%$ & 35 & 105.8 & 30 & 100 \\
\hline $1.5 \%$ & 36 & 111.7 & 31 & 106.6 \\
\hline $2.0 \%$ & 38 & 123.5 & 32 & 113.3 \\
\hline
\end{tabular}




\subsection{Comparison of CBR Values due to Mixing of Jute} Fiber

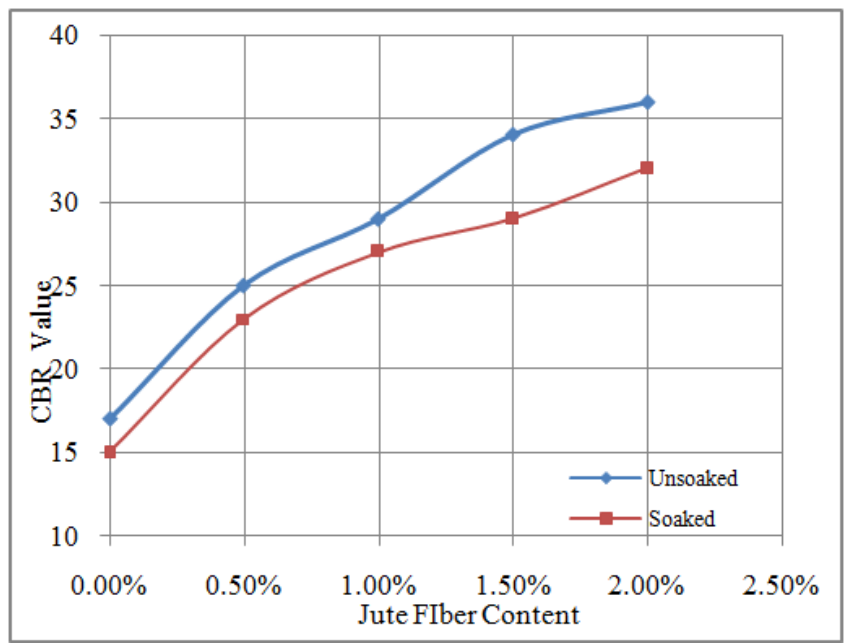

Fig. 4.8. Increased CBR value vs jute fiber $(50 \mathrm{~mm})$ content plot.

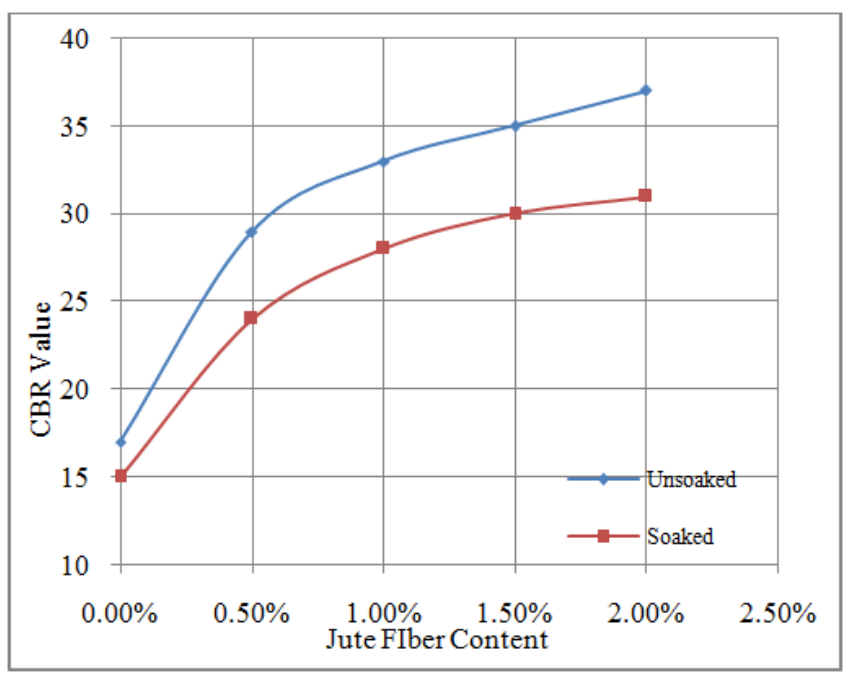

Fig. 4.9. Increased of CBR value vs jute fiber $(100 \mathrm{~mm})$ content plot.

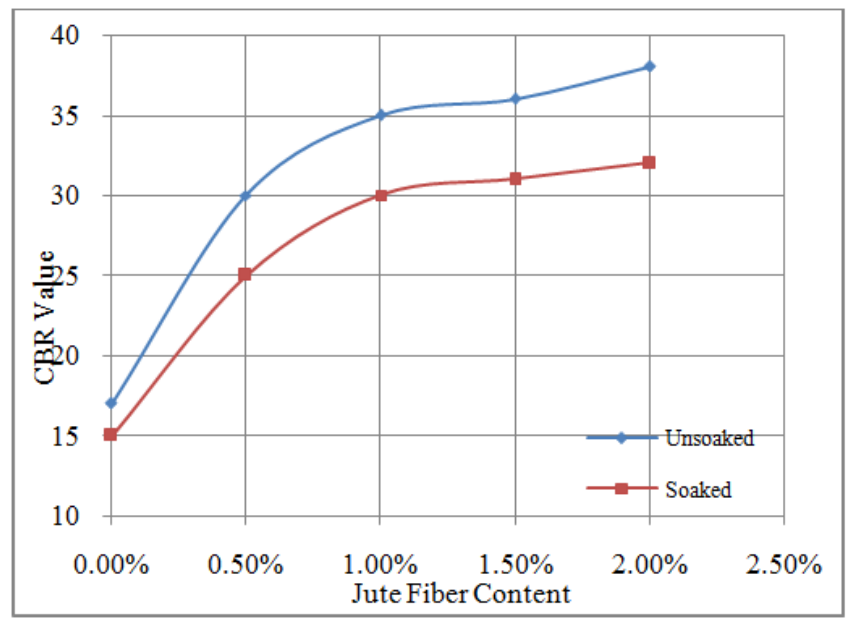

Fig. 4.10. Increased of CBR value vs jute fiber $(150 \mathrm{~mm})$ content plot.

\subsection{CBR Test Results for Various Geotextile Layers}

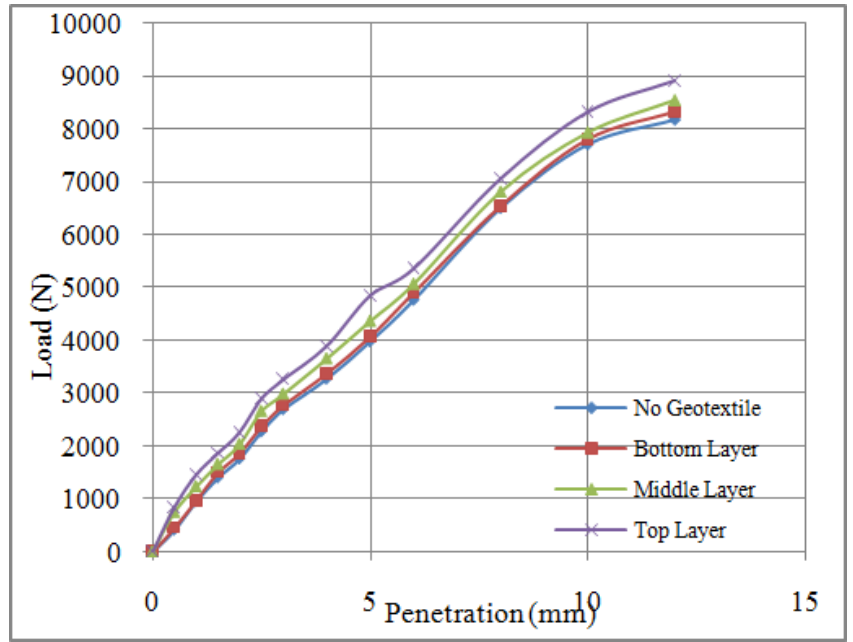

Fig. 4.11. Load vs penetration plot for soil reinforced with single layer of geotextile under soaked condition.

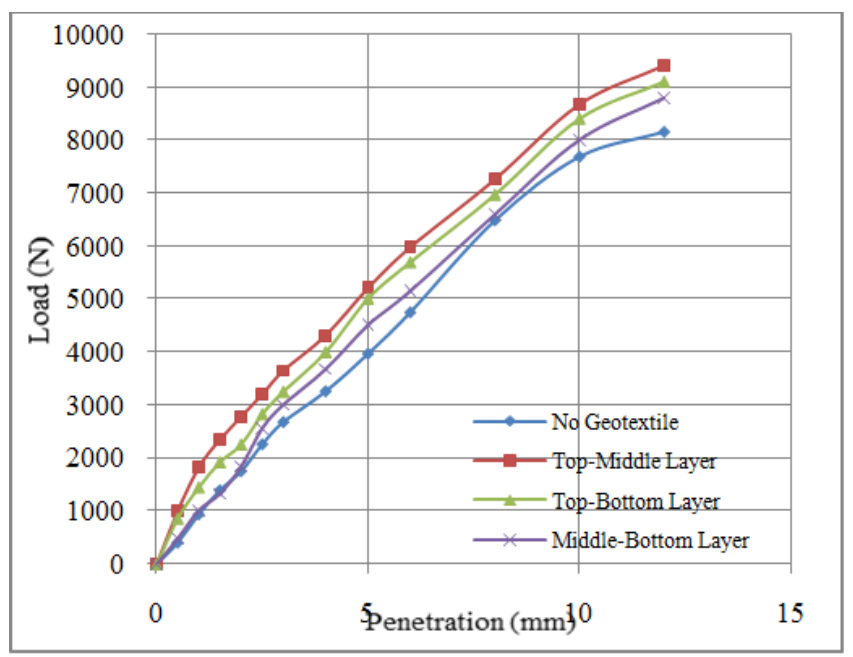

Fig. 4.12. Load vs penetration plot for soil reinforced with double layer of geotextile under soaked condition.

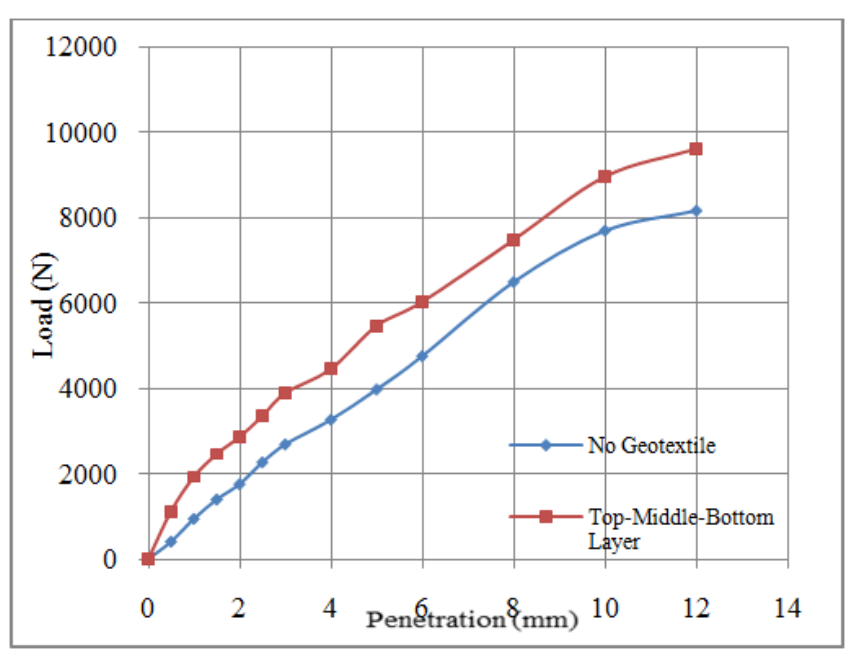

Fig. 4.13. Load vs penetration plot for soil reinforced with triple layer of geotextile under soaked condition. 


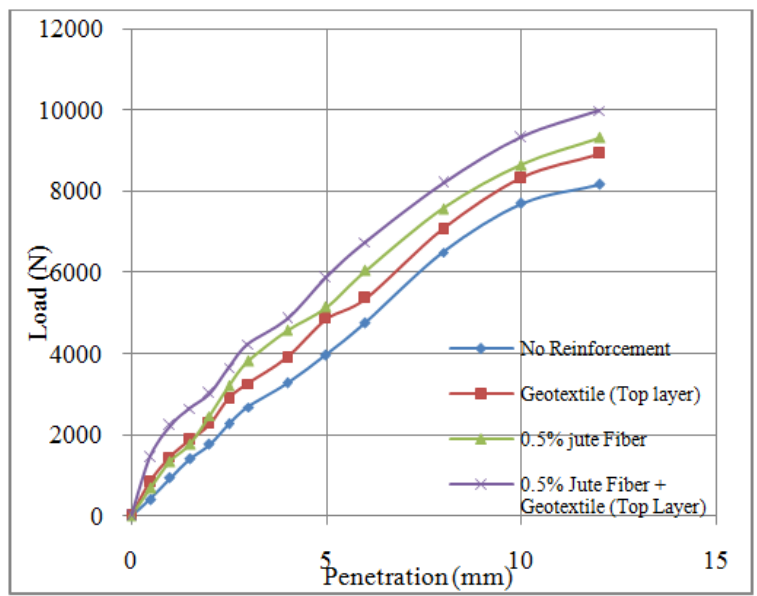

Fig. 4.14. Load vs penetration plot for soil reinforced with 1 layer of geotextile at top and $0.5 \%$ jute fiber $(150 \mathrm{~mm})$ under soaked condition.

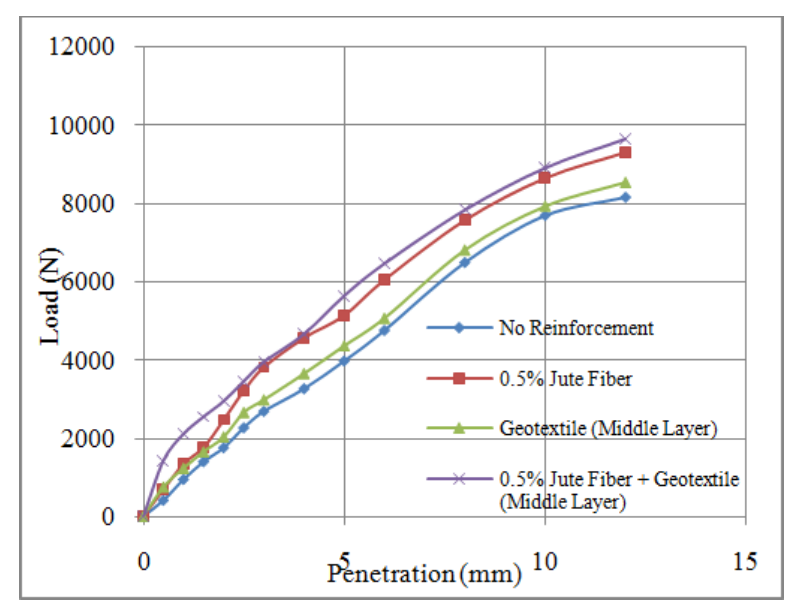

Fig. 4.15. Load vs penetration plot for soil reinforced with 1 layer of geotextile at middle and $0.5 \%$ jute fiber $(150 \mathrm{~mm})$ under soaked condition.

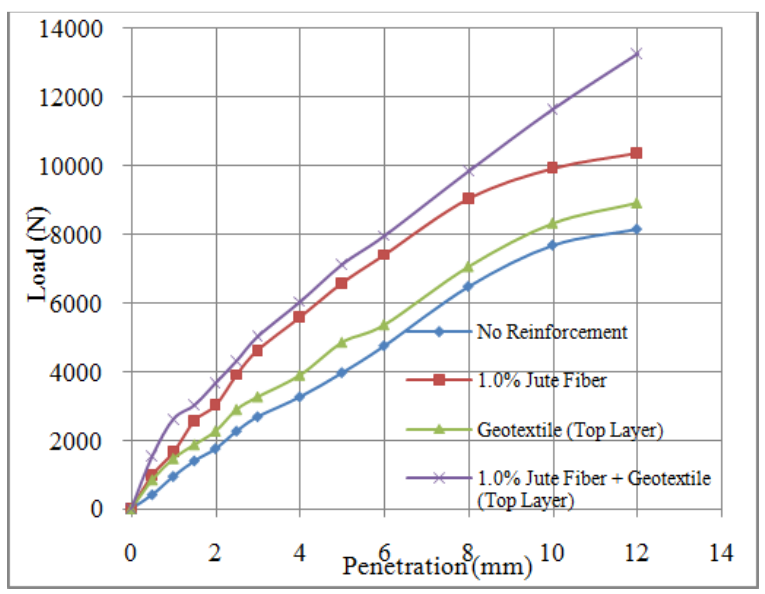

Fig. 4.16. Load vs penetration plot for soil reinforced with 1 layer of geotextile at top and $1.0 \%$ jute fiber $(150 \mathrm{~mm})$ under soaked condition.

Table 4.5. CBR values for soil reinforced with combination of geotextile and jute fiber.

\begin{tabular}{llllll}
\hline Jute & Without & \multicolumn{2}{c}{ One layer at top } & \multicolumn{2}{c}{ One layer at middle } \\
\cline { 3 - 6 } fiber(\%) & Geotextile & CBR & \% Increase & CBR & \% Increase \\
\hline 0.0 & 15 & 19 & 26.6 & 18 & 20 \\
0.5 & 25 & 32 & 113.3 & 31 & 106.6 \\
1.0 & 30 & 51 & 240 & - & - \\
\hline
\end{tabular}

\section{Results and Discussion}

By studying Fig. 4.2, Fig. 4.3, Fig. 4.4, Fig. 4.5, Fig. 4.6, Fig. 4.7 which show the load vs penetration plots of the soil sample with jute fiber reinforcement at various percentages, it can be said that increasing both the percentage of jute fiber and aspect ratio increases the bearing capacity of the soil. Fig. 4.8, Fig. 4.9, Fig. 4.10 shows the increase of CBR value due to adding jute fiber. Fig. 4.11, Fig. 4.12, Fig.4.13 shows the load vs penetration plot for soil reinforced with geotextile. From the Fig. 4.11, Fig. 4.12, Fig.4.13 we can conclude that placing geotextile at top layer is more effective than placing it anywhere else in the soil sample. Fig. 4.14, Fig. 4.15, Fig 4.16 shows the load vs penetration plot for soil reinforced with combination reinforcements discussed above. From Fig. 4.14, Fig. 4.15, Fig 4.16 it can be said that placing the geotextile at top and increasing jute fiber content increases the CBR value most effectively. But from economic point of view increasing the aspect ratio of jute fiber is more effective than increasing its percentage in the mixture.

\section{Conclusion}

The following observations were made on the behavior of unreinforced soil, soil reinforced with geotextile, jute fiber mixed soil and soil reinforced by both geotextile and jute fiber. From the tests performed it is clearly evident that increasing the percentage of geotextile will increase the load bearing capacity of the soil. Though bearing capacity of sample having the same percentage of jute fiber varies with the length of jute fiber used and CBR value increases with the increase of jute fiber which can be observed by studying Table 4.2 , Table 4.3 , Table 4.4 , as a result $50 \mathrm{~mm}$ and $100 \mathrm{~mm}$ jute fibers were rule out in case of combined reinforcement. The effectiveness of geotextiles is governed by the no. of layers used and the placement of the layer. Tests show that placing the layer of geotextile at the top and middle of the soil sample gives the most effective results. The most effective result is achieved by using the geotextile and jute fiber simultaneously. Tests show that a single layer of geotextile coupled with $0.5 \%$ and $1.0 \%$ jute fiber gives almost the same CBR values(Table 4.5) as a sample reinforced with $2 / 3$ layers of geotextile or $1.5 / 2.0 \%$ jute fiber which will effectively reduce the cost of the project. Through the tests performed earlier it is evident that:

1. For jute fiber, CBR value increases with the increase of both fiber content and aspect ratio. It is worth mentioning that the highest amount of change is recorded for $0.5 \%$ and $1.0 \%$ fiber content for all aspect ratios.

2. Tests show that placing of geotextile at top is more effective than placing it at middle or at bottom.

3. Increased layer of both geotextile and length and percentage of jute imparts increasing bearing capacity to the granular subgrade soil.

4. Combination reinforcement with single layer geotextile and only $0.5 \%$ and $1.0 \%$ jute fiber is as effective as two or three layers of geotextile. 


\section{References}

[1] Allahbakhshi, M. and Sadeghi, H. (2014) "Behaviour of industrial machinery foundation on prestressed geogridreinforced embankment over soft soil under static load", Journal of Science Publishing Group, Vol. 2, Issue 6, pp. 6573 .

[2] Al-Moussawi, H.M. and Andersland, O.B. (1987) Discussion on the paper "Behavior of Fabric- versus Fiber- Reinforced Sand", J. Geotech. Engg., ASCE, Vol. 113(7), pp.381-387.

[3] Datta, M. (1999) "Engineering Properties of Coal Ash", Proceedings of Indian Geotechnical Conference, New Delhi, pp.41-45.

[4] Bergado, D.T., Youwai, S., Hai, C.N. and Voottipruex, P. (2001) "Interaction of nonwoven needle-punched geotextiles under axisymmetric loading conditions". Geotextiles and Geomembranes, Vol. 19, pp.299-328

[5] Fannin, R.J., O. Sigurdsson (1996) "Field observations on stabilization of unpaved roads with geosynthetics". Journal of Geotechnical Engineering, ASCE ,122 (7), pp.544-553.

[6] Haeri, S.M., R. Nourzad, A.M. Oskrouch (2000) "Effect of geotextile reinforcement on the mechanical behavior of sands". Geotextiles and Geomembranes 18 (6), pp.385-402.

7] Hossain, M.A., Hossain, M.S. and Hasan, M.K. (2015) "Application of Jute Fiber for the Improvement of Subgrade Characteristics" Journal of Science Publishing Group, Vol. 2, Issue 3, pp. 26-30.

[8] Kaniraj, S.R., and Rao, G.V. (1994) "Trends in the use of geotextiles in India", Journal of geotextiles and geomembranes, pp. 13389 - 402.

[9] Latha, G.M, Murthy, V.S., (2007) "Effects of reinforcement form on the behavior of geosynthetic reinforced sand". Geotextiles and Geomembrane, Vol. 25, pp. 23-32.

[10] Park, T., S.A. Tan (2005) Enhanced performance of reinforced soil walls by the inclusion of short fiber. Geotextiles and Geomembranes, Vol 2 (4), pp. 348-361.

[11] Raymond, G., Ismail, I.,(2003) "The effect of geogrid reinforcement on unbound aggregates". Geotextiles and Geomembranes, Vol. 21, pp.355-380.

[12] Resl, S., Werner, G., (1986) "The influence of nonwoven needle- punched geotextiles on the ultimate bearing capacity of the subgrade". Proceedings of the Third International Conference on Geotextiles, Vienna, Vol. 4, pp. 1009- 1013.

[13] Yetimoglu, T., Salbas, O., (2003) "A study on shear strength of sands reinforced with randomly distributed discrete fibers". Geotextiles and Geomembranes, Vol. 21 (2), pp.103-110. 